\title{
Mitochondrial phylogeny of the deep-sea squat lobsters, Munidopsidae (Galatheoidea)
}

\author{
Shane T. Ahyong ${ }^{\mathrm{a}, *}$, Nikos Andreakis ${ }^{\mathrm{b}}$, Joanne Taylor ${ }^{\mathrm{c}}$ \\ a Australian Museum, 6 College St., Sydney, NSW 2010, Australia \\ ${ }^{\mathrm{b}}$ Australian Institute of Marine Science, PMB 3, Townsville MC, QLD 4810, Australia \\ ${ }^{\mathrm{c}}$ Museum Victoria, GPO Box 666, Melbourne, VIC 3001, Australia
}

Received 20 May 2011; received in revised form 23 June 2011; accepted 23 June 2011

Corresponding Editor: S. De Grave

\begin{abstract}
The Munidopsidae, one of three squat lobster families in the Galatheoidea, contains the deepest dwelling squat lobsters, with some occurring at abyssal depths. Munidopsids were formerly divided into two subfamilies: Shinkaiinae, for the unusual hydrothermal vent genus Shinkaia; and Munidopsinae for remaining taxa. Four munidopsid genera are currently recognised (Shinkaia, Leiogalathea, Galacantha and Munidopsis) but the largest genus, Munidopsis, is highly diverse morphologically, with multiple genera or subgenera currently in its synonymy. Phylogenetic studies of galatheoids focussed on high level relationships indicate that Leiogalathea is sister to other munidopsids, but the position of Shinkaia with respect to Munidopsis and Galacantha is unclear, as is the reciprocal monophyly of the latter two genera. Phylogenetic analyses of the Munidopsidae based on mitochondrial $16 \mathrm{~S}$ and COI sequences, sampling all current genera (including the majority of the formerly recognised subgenera), indicate that the generic and former subfamily classifications do not reflect the phylogeny. Shinkaia and Galacantha clades are nested within Munidopsis rendering the genus paraphyletic and the bi-subfamily classification phylogenetically invalid. Many of the Munidopsis clades recovered, however, correspond well to formerly recognised genera or subgenera, indicating good prospects for a natural subdivision of Munidopsis.

Crown Copyright @ 2011 Published by Elsevier GmbH. All rights reserved.
\end{abstract}

Keywords: Crustacea; Decapoda; Squat lobster; Munidopsis; Molecular phylogeny

\section{Introduction}

The squat lobster family Munidopsidae includes the deepest dwelling members of the Galatheoidea, and many have correspondingly reduced eyes for life in low light on the outer continental shelf, slope or abyssal plain. The munidopsids are sister to the remaining galatheoids and also have

\footnotetext{
* Corresponding author.

E-mail addresses: Shane.ahyong@austmus.gov.au (S.T. Ahyong), n.andreakis@aims.gov.au (N. Andreakis),jtaylor@museum.vic.gov.au (J. Taylor).
}

the distinction of being the geologically oldest of the squat lobsters, with a fossil record dating back to the Lower Jurassic (Schweitzer and Feldmann, 2000; Ahyong et al., 2009). The Munidopsidae are distinguished from other galatheoids by their chief synapomorphy: the loss or reduction of the flagellum on maxilliped 1 (Ahyong et al., 2010).

Two munidopsid subfamilies are recognised: Shinkaiinae, for the unusual hydrothermal vent genus Shinkaia (Fig. 1K); and Munidopsinae for remaining taxa (Baba and Williams, 1998). Recently, the Galathea-like Leiogalathea (Fig. 1J) was shown to be a munidopsid, as sister to the Shinkaia + Galacantha + Munidopsis clade (Ahyong et al., 


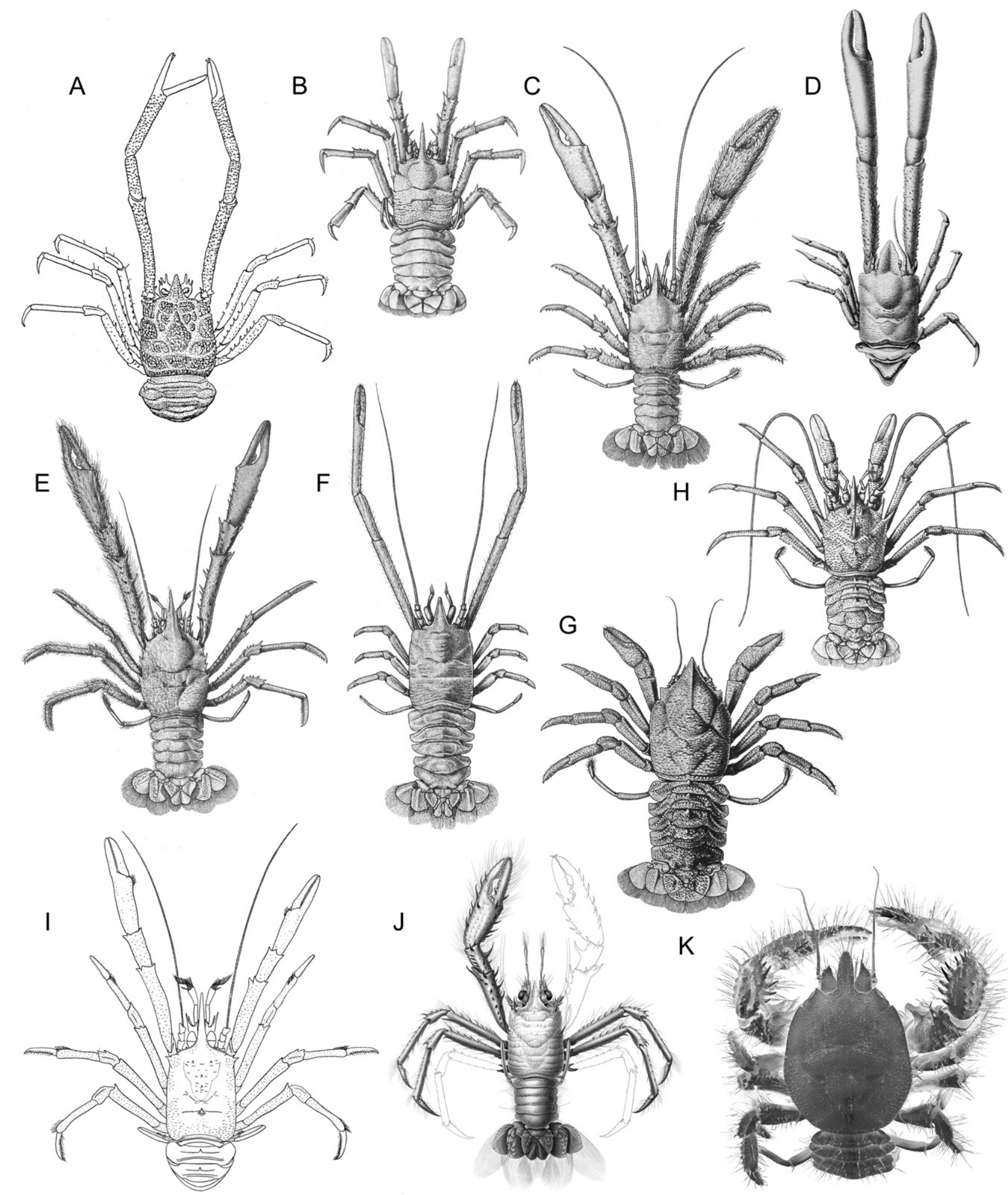

Fig. 1. Representatives of genera of Munidopsidae and groups within Munidopsis. (A) Anoplonotus group (M. granulata Miyake and Baba, 1967); (B) Bathyankyristes group (M. levis Alcock and Anderson, 1894); (C) Dasypus group (M. dasypus Alcock, 1894); (D) Elasmonotus group (M. longimanus Milne-Edwards, 1880); (E) Galathodes group (M. trifida Henderson, 1885); (F) Galathopsis group (M. cylindrophthalma Alcock, 1894); (G) Orophorhynchus group (M. granosa Alcock, 1901); (H) Galacantha rostrata Milne-Edwards, 1880; (I) Munidopsis curvirostra Whiteaves, 1874; (J) Leiogalathea laevirostris (Balss, 1913); (K) Shinkaia crosnieri Baba and Williams, 1998 (A, modified from Miyake and Baba, 1967; B, from Alcock and McArdle, 1901; C and E, from Alcock and MacGilchrist, 1905; D, from Milne-Edwards and Bouvier, 1897; F and H, from Alcock and Anderson, 1895; G, from Alcock and McArdle, 1902; I, from Selbie, 1914; J, from Doflein and Balss, 1913; K, modified from Baba and Williams, 1998). 
2009; Schnabel et al., 2011). Thus, Munidopsidae currently includes four genera: Leiogalathea and members of the subfamilies, Shinkaiinae (Shinkaia) and Munidopsinae (Munidopsis and Galacantha). Only one and two extant species Shinkaia and Leiogalathea are known, respectively, but there are more than 230 species of Galacantha and Munidopsis worldwide (Baba et al., 2008). In particular, Munidopsis is highly diverse morphologically with as many as seven genera or subgenera recognised by past workers for species now placed there (Fig. 1A-I).

Phylogenetic relationships within Munidopsidae have not been examined in detail and studies within Munidopsis have focused only on small species clusters or small regional groups (e.g., Creasey et al., 2000; Cubelio et al., 2007; Jones and Macpherson, 2007). Although Leiogalathea has been identified as sister to other munidopsids, the position of Shinkaia with respect to Munidopsis and Galacantha is unclear, as is the reciprocal monophyly of the latter two genera. In addition, several Mesozoic fossil munidopsid genera appear to fall within the currently broad concept of Munidopsis (Ahyong et al., 2010) and may represent diagnosable clades within the genus. Generic names aside, determining the phylogenetic placement of these fossils is necessary for the most reliable estimates of munidopsid divergence times. A well-resolved phylogeny of the munidopsids is thus a necessary first step in understanding the evolution of the group. Here, we assess whether the generic and subfamily classification of the Munidopsidae reflects phylogenetic relationships inferred from mitochondrial $16 \mathrm{~S}$ and $\mathrm{COI}$ sequences of selected munidopsid species.

\section{Materials and methods}

\subsection{Terminal taxa}

Representatives of all recognised munidopsid genera were included as ingroup terminals (Table 1). COI and 16S sequences of Shinkaia, Leiogalathea and selected Munidopsis and Galacantha species derived from GenBank. The voucher specimen corresponding to a published GenBank sequence EU920928, originally identified as Munidopsis rostrata (see Toon et al., 2009) was re-identified as Galacantha valdiviae based on photographs provided by $\mathrm{H}$. Bracken (Brigham Young University, Utah). Mitochondrial DNA sequences of remaining Munidopsis and Galacantha terminals were derived from ethanol preserved specimens in the collections of Museum Victoria, Melbourne (NMV), the National Institute of Water and Atmospheric Research, Wellington (NIWA), the University of Louisiana at Lafayette, Louisiana (ULL), and the Universidad Católica del Norte, Coquimbo (UCN). The Munidopsidae is sister to the remaining galatheoids (Ahyong et al., 2009; Schnabel et al., 2011), so analyses were rooted to selected Galatheidae and Munididae.

\subsection{DNA extraction, PCR amplification and sequencing}

Total DNA was extracted from ca. $50 \mathrm{mg}$ ethanol preserved abdominal tissue or pereopod of the target specimen following the salt-based extraction procedure described by Aljanabi and Martinez (1997) with minor modifications. Quantity and quality of DNA were examined by means of $1 \%$ agarose TAE buffer gel electrophoresis against known standards. Partial COI and $16 \mathrm{~S}$ sequences were PCR-amplified using the primer pair LCO1490-HCO2198 described by Folmer et al. (1994) and 16Sarl-16Sbrh described by Palumbi and Benzie (1991), respectively. Standard PCR reactions were performed in $30 \mu \mathrm{l}$ of medium containing approximately $10 \mathrm{ng}$ DNA, $1.5 \mathrm{mM} \mathrm{MgCl}_{2}, 0.2 \mathrm{mM}$ dNTPs, $1 \mu \mathrm{M}$ of forward and reverse primers each, $1 \times$ PCR reaction buffer and 1.25 units of $i$ Taq DNA polymerase (Scientifix). The amplification cycle for the partial COI marker included an initial denaturation at $94{ }^{\circ} \mathrm{C}$ for $4 \mathrm{~min}$ followed by 35 cycles of $94^{\circ} \mathrm{C} 1 \mathrm{~min}, 50{ }^{\circ} \mathrm{C}$ $1 \mathrm{~min}$ and $72^{\circ} \mathrm{C} 1.5 \mathrm{~min}$ followed by a final extension cycle at $72{ }^{\circ} \mathrm{C}$ for $7 \mathrm{~min}$. The partial $16 \mathrm{~S}$ gene was amplified under the same conditions except for the lower annealing temperature $\left(45^{\circ} \mathrm{C}\right)$. Quantity and length of the PCR-products were examined by $1 \%$ gel electrophoresis as described above. Multiple amplification products were never observed. PCR reactions were sent to Macrogen Inc. (Korea; www.macrogen.com) for purification and direct sequencing on both directions.

\subsection{Sequence alignments and phylogenetic analysis}

Electropherograms were assembled in Sequencher 4.9 (Gene Codes) and partial COI sequences aligned manually in Bioedit v7.0.9 (Hall, 1999). Since many regions of the partial $16 \mathrm{~S}$ gene are extremely divergent and may produce unreliable alignments, sequences were either aligned in Bioedit using ClustalW algorithm (Thompson et al., 1994) with several gap openings and extension penalties or in MUSCLE (http://www.ebi.ac.uk/Tools/muscle/index.html), the latter known to achieve the highest accuracy scores (Edgar, 2004). Three alignments (COI, 16S and concatenated COI-16S) were considered for phylogenetic analysis; $16 \mathrm{~S}$ and COI-16S alignments were refined by eye. Alignment gaps were treated as missing data.

Phylogenetic information content in each partition was assessed by calculating $g_{1}$ statistics as a measure of the skewness of distribution of tree-lengths among 10,000 random maximum parsimony trees (Hillis and Huelsenbeck, 1992) in PAUP*4.0b10 for Windows (Swofford, 2002). The significance of the $g_{1}$ value was compared with critical values $(p=0.01)$ for four state characters given the number of distinct sequences and the number of parsimony informative sites. Hierarchical Likelihood Ratio Tests (hLRTs) were run in Modeltest Version 3.7 (Posada and Crandall, 1998) to identify the best-fitting model and parameters (gamma distri- 
Table 1. Classification of terminal taxa and GenBank accession numbers. Collecting locality and institutional registration numbers given for voucher specimens of new sequences. Abbreviations: Museum Victoria, Melbourne (NMV); National Institute of Water and Atmospheric Research, Wellington (NIWA); the University of Louisiana at Lafayette, Louisiana (ULLZ); Universidad Católica del Norte, Coquimbo (UCN); Brigham Young University, Utah (BYU). Note: the 16S sequence of Galacantha valdiviae (EU920928) was originally published as Munidopsis rostrata (see Toon et al., 2009).

\begin{tabular}{|c|c|c|c|c|}
\hline Taxon & $\mathrm{COI}$ & $16 \mathrm{~S}$ & Locality & Museum no. \\
\hline \multicolumn{5}{|l|}{ Munidopsidae } \\
\hline Galacantha diomedeae & $\mathrm{JN} 166758^{\mathrm{a}}$ & $\mathrm{JN} 166748^{\mathrm{a}}$ & Chile & UCN G3b \\
\hline Galacantha rostrata 1 & $\mathrm{JN} 166755^{\mathrm{a}}$ & $\mathrm{JN} 166751^{\mathrm{a}}$ & Tasman Sea & NIWA 28060a \\
\hline Galacantha rostrata 2 & & HQ380261 & Tasman Sea & NIWA $28060 b$ \\
\hline Galacantha quiquei & $\mathrm{JN} 166754^{\mathrm{a}}$ & $\mathrm{JN} 166744^{\mathrm{a}}$ & Tasman Sea & NIWA 28088 \\
\hline Galacantha spinosa 1 & $\mathrm{JN} 166769^{\mathrm{a}}$ & $\mathrm{JN} 166752^{\mathrm{a}}$ & N Gulf of Mexico & ULL Z-10852 \\
\hline Galacantha spinosa 2 & $\mathrm{JN} 166768^{\mathrm{a}}$ & $\mathrm{JN} 166753^{\mathrm{a}}$ & N Gulf of Mexico & ULL Z-8023 \\
\hline Galacantha subspinosa 1 & $\mathrm{JN} 166760^{\mathrm{a}}$ & $\mathrm{JN} 166745^{\mathrm{a}}$ & NW Australia & NMV J56403a \\
\hline Galacantha subspinosa 2 & $\mathrm{JN} 166756^{\mathrm{a}}$ & $\mathrm{JN} 166746^{\mathrm{a}}$ & NW Australia & NMV J56403b \\
\hline Galacantha subspinosa 3 & $\mathrm{JN} 166761^{\mathrm{a}}$ & $\mathrm{JN} 166750^{\mathrm{a}}$ & NW Australia & NMV J56403c \\
\hline Galacantha subspinosa 4 & $\mathrm{JN} 166762^{\mathrm{a}}$ & $\mathrm{JN} 166747^{\mathrm{a}}$ & NW Australia & NMV J56403d \\
\hline Galacantha subspinosa 5 & $\mathrm{JN} 166757^{\mathrm{a}}$ & $\mathrm{JN} 166749^{\mathrm{a}}$ & NW Australia & NMV J56403e \\
\hline Galacantha valdiviae & & EU920928 & Japan & BYU KC3102 \\
\hline Leiogalathea laevirostris 1 & AY351055 & EU821541 & & \\
\hline Leiogalathea laevirostris 2 & & AY351252 & & \\
\hline Munidopsis abbreviata & $\mathrm{JN} 166771^{\mathrm{a}}$ & JN166724 & N Gulf of Mexico & ULLZ-10848 \\
\hline Munidopsis bairdii & & EU821542 & & \\
\hline Munidopsis bracteosa & DQ677689 & & & \\
\hline Munidopsis comarge & $\mathrm{JN} 166772^{\mathrm{a}}$ & $\mathrm{JN} 166732^{\mathrm{a}}$ & New Zealand & NIWA 53792 \\
\hline Munidopsis crenatirostris 1 & $\mathrm{JN} 166783^{\mathrm{a}}$ & $\mathrm{JN} 166736^{\mathrm{a}}$ & NW Australia & NMV J56399 \\
\hline Munidopsis crenatirostris 2 & $\mathrm{JN} 166781^{\mathrm{a}}$ & $\mathrm{JN} 166738^{\mathrm{a}}$ & NW Australia & NMV J57252 \\
\hline Munidopsis crenatirostris 3 & $\mathrm{JN} 166778^{\mathrm{a}}$ & $\mathrm{JN} 166733^{\mathrm{a}}$ & NW Australia & NMV J56397 \\
\hline Munidopsis crenatirostris 4 & $\mathrm{JN} 166780^{\mathrm{a}}$ & & NW Australia & NMV J55009a \\
\hline Munidopsis crenatirostris 5 & $\mathrm{JN} 166779^{\mathrm{a}}$ & $\mathrm{JN} 166742^{\mathrm{a}}$ & NW Australia & NMV J55009b \\
\hline Munidopsis crenatirostris 6 & $\mathrm{JN} 166782^{\mathrm{a}}$ & $\mathrm{JN} 166743^{\mathrm{a}}$ & NW Australia & NMV J55009c \\
\hline Munidopsis curvirostra 1 & FJ581770 & & & \\
\hline Munidopsis curvirostra 2 & FJ581769 & & & \\
\hline Munidopsis curvirostra 3 & FJ581768 & & & \\
\hline Munidopsis cylindrophthalma & $\mathrm{JN} 166784^{\mathrm{a}}$ & $\mathrm{JN} 166737^{\mathrm{a}}$ & NW Australia & NMV J55128 \\
\hline Munidopsis dasypus 1 & $\mathrm{JN} 166774^{\mathrm{a}}$ & $\mathrm{JN} 166727^{\mathrm{a}}$ & NW Australia & NMV J56121 \\
\hline Munidopsis dasypus 2 & $\mathrm{JN} 166776^{\mathrm{a}}$ & & NW Australia & NMV J57251 \\
\hline Munidopsis dasypus 3 & $\mathrm{JN} 166777^{\mathrm{a}}$ & $\mathrm{JN} 166729^{\mathrm{a}}$ & NW Australia & NMV J57250a \\
\hline Munidopsis dasypus 4 & $\mathrm{JN} 166773^{\mathrm{a}}$ & $\mathrm{JN} 166730^{\mathrm{a}}$ & NW Australia & NMV J57250b \\
\hline Munidopsis erinacea & $\mathrm{JN} 166767^{\mathrm{a}}$ & $\mathrm{JN} 166731^{\mathrm{a}}$ & N Gulf of Mexico & ULLZ-7810 \\
\hline Munidopsis kensleyi & $\mathrm{JN} 166775^{\mathrm{a}}$ & $\mathrm{JN} 166728^{\mathrm{a}}$ & NW Australia & NMV J62313 \\
\hline Munidopsis levis & & $\mathrm{JN} 166723^{\mathrm{a}}$ & NW Australia & NMV J55125 \\
\hline Munidopsis longimanus & $\mathrm{JN} 166770^{\mathrm{a}}$ & $\mathrm{JN} 166741^{\mathrm{a}}$ & N Gulf of Mexico & ULL Z-10851 \\
\hline Munidopsis opalescens 1 & & JN166739a & Chile & UCN G4 \\
\hline Munidopsis opalescens 2 & $\mathrm{JN} 166759^{\mathrm{a}}$ & $\mathrm{JN} 166740^{\mathrm{a}}$ & Chile & UCN G7 \\
\hline Munidopsis polymorpha & DQ860146 & & & \\
\hline Munidopsis quadrata 1 & $\mathrm{JN} 166766^{\mathrm{a}}$ & $\mathrm{JN} 166734^{\mathrm{a}}$ & Chile & UCN G1 \\
\hline Munidopsis quadrata 2 & DQ882093 & & & \\
\hline Munidopsis recta & DQ677702 & EF428964 & & \\
\hline Munidopsis trifida 1 & $\mathrm{JN} 166764^{\mathrm{a}}$ & $\mathrm{JN} 166725^{\mathrm{a}}$ & Chile & UCN G9 \\
\hline Munidopsis trifida 2 & $\mathrm{JN} 166765^{\mathrm{a}}$ & $\mathrm{JN} 166726^{\mathrm{a}}$ & Chile & UCN G10 \\
\hline Munidopsis sp. & $\mathrm{JN} 166763^{\mathrm{a}}$ & $\mathrm{JN} 166735^{\mathrm{a}}$ & Chile & UCN G8 \\
\hline Shinkaia crosnieri 1 & EU420129 & EU420129 & & \\
\hline Shinkaia crosnieri 2 & NC011013 & NC011013 & & \\
\hline \multicolumn{5}{|l|}{ Outgroups } \\
\hline Alainius crosnieri 1 & AY351050 & AY351238 & & \\
\hline Alainius crosnieri 2 & & AY351239 & & \\
\hline Galathea sp. 1 & GQ260875 & EU821544 & & \\
\hline
\end{tabular}


Table 1 (Continued)

\begin{tabular}{|c|c|c|c|c|}
\hline Taxon & $\mathrm{COI}$ & $16 \mathrm{~S}$ & Locality & Museum no. \\
\hline Galathea sp. 2 & GQ260877 & & & \\
\hline Munida compressa & AY350944 & AY351114 & & \\
\hline Munida rubridigitalis & AF283887 & AY351163 & & \\
\hline Munida thoe & AY351009 & AY351182 & & \\
\hline Pleuroncodes monodon 1 & AY351062 & AY351259 & & \\
\hline Pleuroncodes monodon 2 & & EU821545 & & \\
\hline Sadayoshia sp. & & EU821547 & & \\
\hline
\end{tabular}

${ }^{a}$ New sequences are marked.

bution, proportion of invariable sites, transition-transversion ratio) for Bayesian inference (BI) and maximum likelihood (ML) analyses given the alignment. The GTR substitution model was used when the Modeltest output could not be implemented in MrBayes. In these cases model parameters were treated as unknown variables with uniform default priors and were estimated as part of the analysis. Maximum likelihood phylogenies were computed in PAUP*. Bayesian inference was implemented in MrBayes v3.1.2 (Huelsenbeck and Ronquist, 2001). Optimal models of nucleotide evolution for BI and ML were identified by Modeltest. ML heuristic searches were run in PAUP* (random addition sequence; TBR branch swapping; 10 replicates). BI was conducted for $5,000,000$ generations of two parallel runs of four chains each, starting from a random tree and sampling every 1000 generations. The convergence of the parameter estimates was graphically confirmed by plotting values of likelihood against the generation time in Tracer v1.5 (Rambaut and Drummond, 2007). Non-parametric bootstrap support (Felsenstein, 1985) for individual clades was estimated in PhyML v3.0 (Guindon and Gascuel, 2003) on 1000 pseudoreplicates using the same methods, options and constraints used for the ML treeinferences.

\section{Results}

\subsection{Sequences and alignments}

Sixty-two new sequences (31 each of COI and 16S rDNA) obtained from 18 species were merged with publically available munidopsid and outgroup sequences to create three alignments: COI, $16 \mathrm{~S}$ and a concatenated COI-16S (see Table 1 for specimen information and Table 2 for alignment length, model selection and summary statistics). The COI and 16S partitions comprised 503 (43\% parsimony informative) and 513 positions (44\% parsimony informative), respectively. Both COI and $16 \mathrm{~S}$ sequences were AT rich. Average base composition was $\mathrm{A}=27.1 \%, \mathrm{C}=18.1 \%, \mathrm{G}=17.9 \%$, $\mathrm{T}=36.9 \%$ for $\mathrm{COI} ; \mathrm{A}=35.8 \%, \mathrm{C}=10.1 \%, \mathrm{G}=18.0 \%$, $\mathrm{T}=36.1 \%$ for $16 \mathrm{~S}$. The length distribution of 10,000 random trees computed for each alignment was considerably left- skewed indicating significant amount of phylogenetic signal in the datasets (Table 2).

\subsection{Phylogenetic analyses}

Topologies derived from individual genes under ML and BI were similar to those derived from combined analyses, all of which show that Munidopsis is not monophyletic (Figs. 2 and 3). The chief differences between the COI and $16 \mathrm{~S}$ topologies are in the composition of Galacantha and positions of Leiogalathea and Shinkaia. The phylogenies inferred from the COI gene (Fig. 2A) resolve a Galacantha clade that includes Munidopsis abbreviata (Milne-Edwards, 1880) (although with equivocal nodal support for its position); Shinkaia is sister to the clade of hydrothermal vent species [Munidopsis bairdii (Smith, 1884) and Munidopsis bracteosa Jones and Macpherson, 2007]; and Leiogalathea is nested between the hydrothermal vent clade and the remaining munidopsids. In the $16 \mathrm{~S}$ topologies (Fig. 2B), Galacantha is monophyletic, apart from Galacantha diomedeae Faxon, 1893, which stands as sister to all other munidopsids; Shinkaia is not sister to the hydrothermal vent clade of Munidopsis, although the two clades are in 'close' proximity.

The combined analysis resolves Galacantha as monophyletic (to the exclusion of G. diomedeae); Shinkaia and hydrothermal vent species of Munidopsis form a distinct clade in line with the single-gene topologies; and Leiogalathea is resolved as sister to the remaining munidopsids corroborating previous studies based on combined nuclear and mitochondrial markers (Ahyong et al., 2009; Schnabel et al., 2011). Our discussion to follow focuses on the results of the combined analyses, being based on the most substantial dataset.

\section{Discussion}

The phylogeny of Mundopsidae inferred herein is not compatible with relationships implied by the former subfamily classification (Baba and Williams, 1998). Shinkaia is nested within the Munidopsis-Galacantha clade irrespective of the data partition or analysis method used. Thus, Shinkaiinae and 
Table 2. Sequence and alignment statistics. $l$, alignment length; $n$, number of sequences; $h$, number of unique haplotypes; $g_{1}$, phylogenetic informativeness of the data; $m$, evolutionary model selected by Modeltest; $i$, proportion of invariant sites; $a$, Gamma distribution shape parameter; $v$, variable, parsimony uninformative sites; $p$, parsimony informative sites.

\begin{tabular}{llllllllll}
\hline & $l$ & $n$ & $h$ & $g_{1}$ & $m$ & $i$ & $a$ & $v$ & $p$ \\
\hline COI & 503 & 45 & 41 & -0.68 & GTR + I + G & 0.4740 & 0.7620 & 19 & 216 \\
16S & 513 & 45 & 39 & -0.61 & TVM + G & 0.3918 & 0.3496 & 51 & 226 \\
COI-16S & 1016 & 51 & 50 & -0.64 & TVM + I + G & 0.4324 & 0.8037 & 82 & 462 \\
\hline
\end{tabular}

Munidopsinae are not reciprocally monophyletic, although based on the complete dataset $(16 \mathrm{~S}+\mathrm{COI})$, they form a clade that is sister to Leiogalathea, corroborating analyses of higher level anomuran interrelationships based on combined $16 \mathrm{~S}$ + nuclear $18 \mathrm{~S}$ and $28 \mathrm{~S}$ sequences (Ahyong et al., 2009; Schnabel et al., 2011).

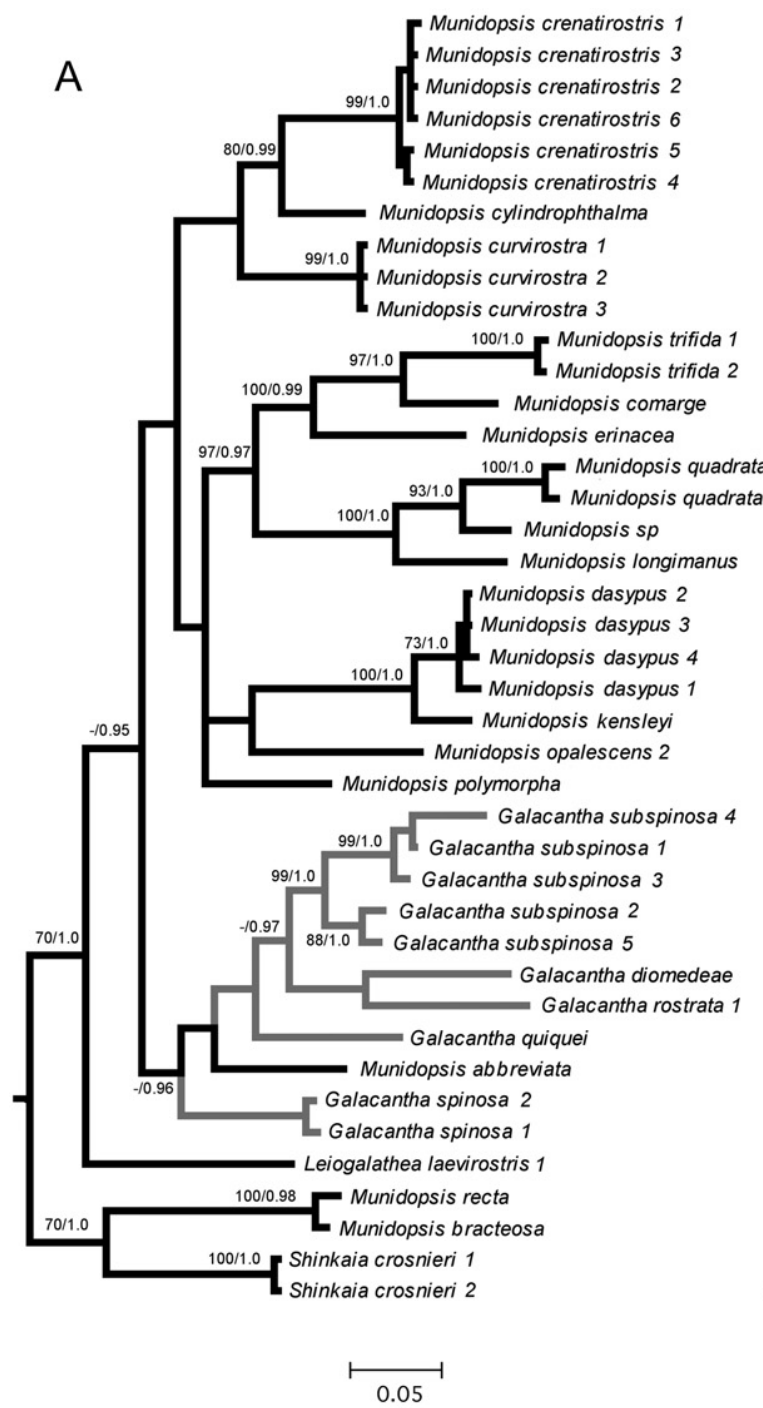

The 'basal' position of Leiogalathea (Fig. 1J) follows morphological expectations given its plesiomorphic, well-developed eyes and Galathea-like habitus. Of all munidopsids, Leiogalathea has the most Galathea-like body form - the broad triangular rostrum, well-developed eyes, and sparsely ornamented carapace and abdomen, leading

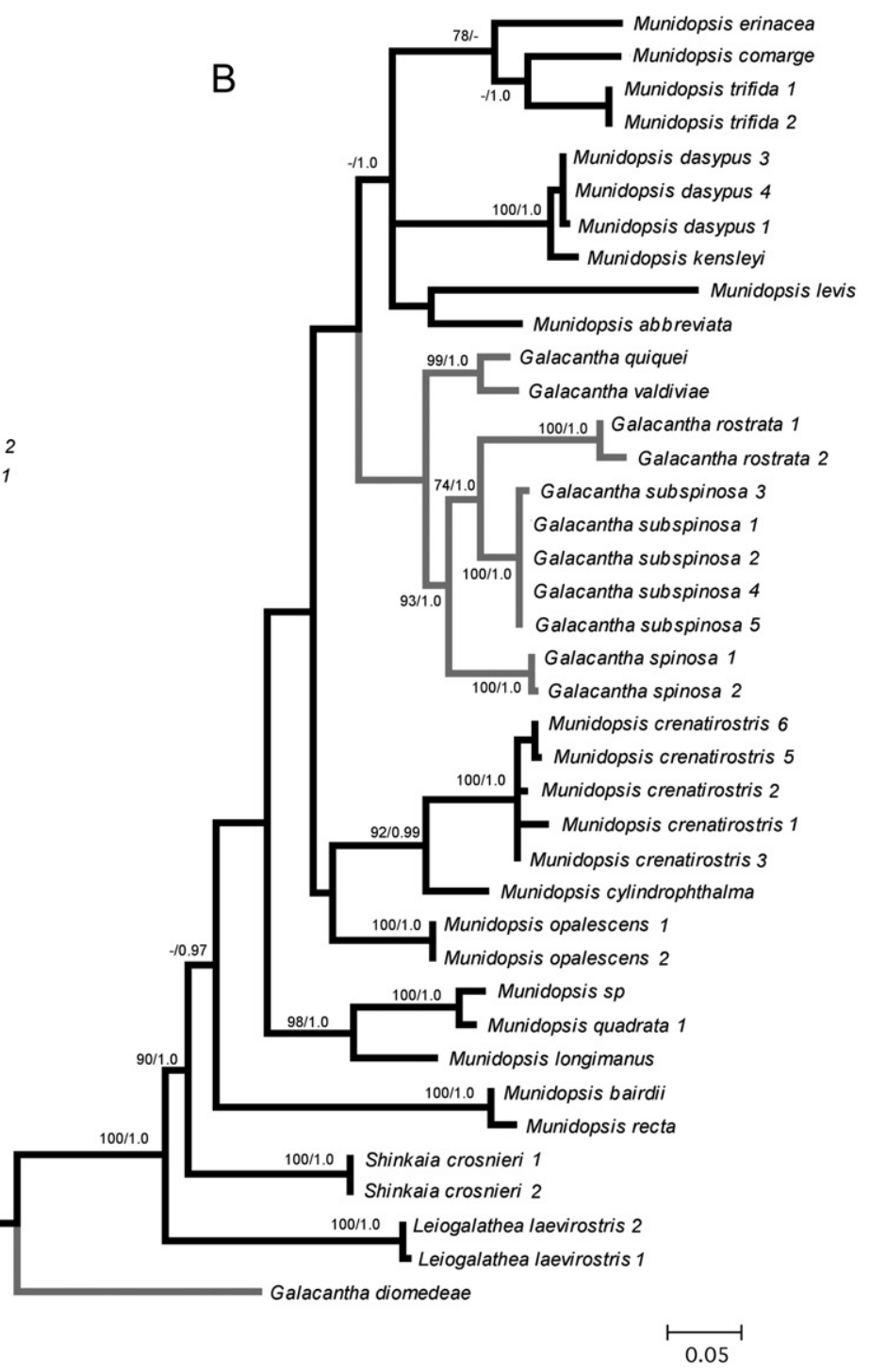

Fig. 2. Phylogeny of Munidopsidae. (A) Bayesian phylogram based partial COI sequences ( $\ln L=-5520.28165$ ); (B) maximum likelihood phylogram based on partial 16S rDNA sequences $(\ln L=-12160.17532)$. Species of Galacantha are marked in gray. Numbers on nodes indicate non-parametric bootstrap support (maximum likelihood) and posterior probabilities (Bayesian inference). Only values at or above $70 \%$ and 0.95 for bootstrap and posterior probability, respectively, are reported. Slight differences in taxonomic representation between COI and $16 \mathrm{~S}$ topologies reflect incomplete sampling of both amplicons for some species. 


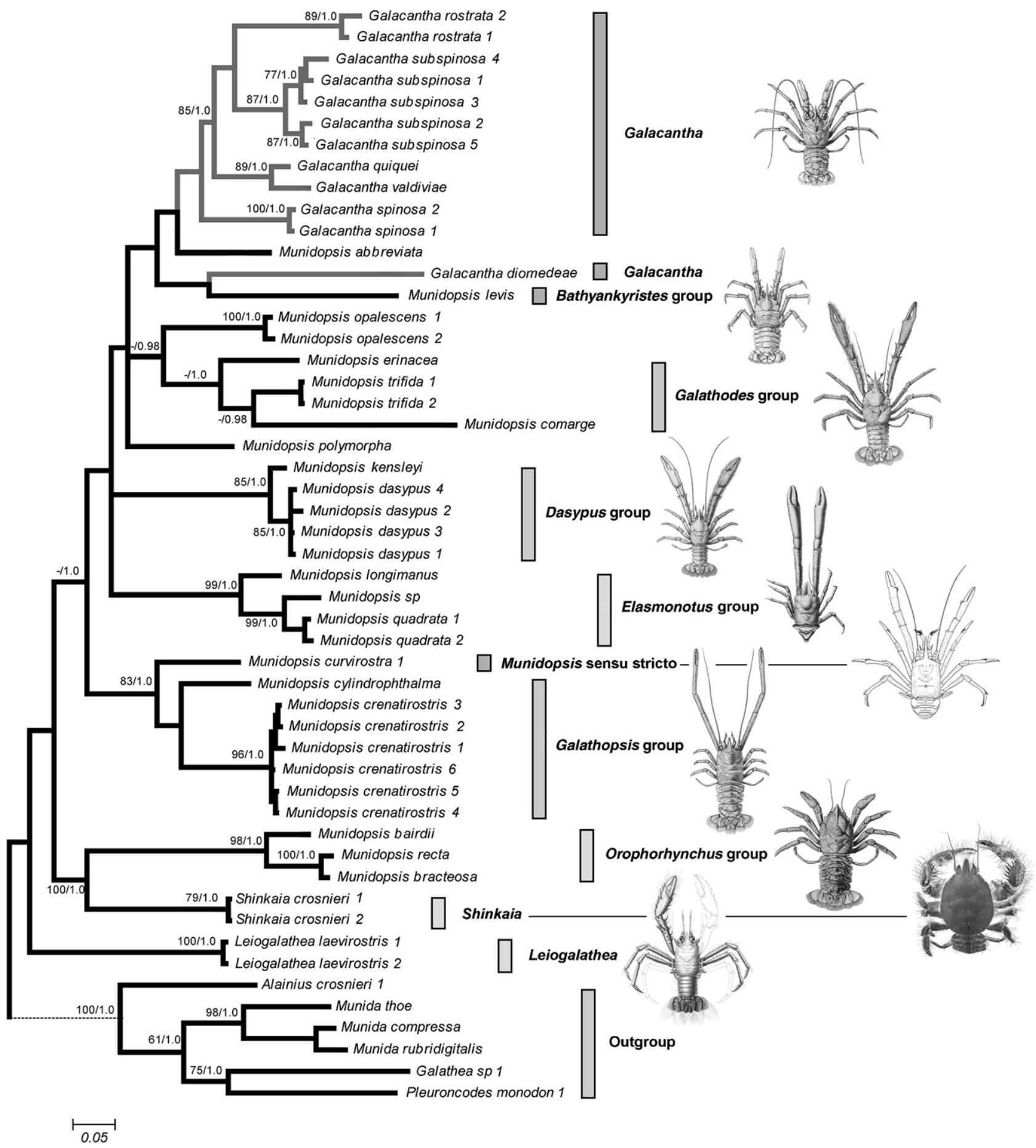

Fig. 3. Bayesian phylogram of Munidopsidae based on combined COI and $16 \mathrm{~S}$ rDNA gene sequences $(\ln L=-10960.98154)$. Species of Galacantha are marked in gray. Numbers on nodes indicate non-parametric bootstrap support (maximum likelihood) and posterior probabilities (Bayesian inference). Only values above at or above $60 \%$ and 0.95 for bootstrap and posterior probability, respectively, are reported.

to its original classification alongside Galathea and Allogalathea (Galatheidae). The reduced maxilliped 1 flagellum of Leiogalathea is transitional between the well-developed condition (plesiomorphic) of munidids and galatheids, and the complete loss of the flagellum in remaining munidopsids (derived). Leiogalathea could also be considered to be ecologically transitional, occurring on the continental shelf and upper slope as in munidids, rather than the outer slope or abyssal habitats of most other munidopsids.

Galacantha and Shinkaia stand deeply nested among clades of Munidopsis indicating that the current concept of Munidopsis (Baba et al., 2008) is not monophyletic. This result is not unexpected given the high morphological diversity within Munidopsis sensu lato. Past workers have 
attempted to represent this diversity through many generic divisions for those species now placed in Munidopsis or Galacantha: Anoplonotus Smith, 1883; Bathyankyristes Alcock and Anderson, 1894; Elasmonotus Milne-Edwards, 1880; Galathopsis Henderson, 1885; Galathodes Milne-Edwards, 1880; and Orophorhynchus Milne-Edwards, 1880 (Fig. 1). Most workers in the 19th and early 20th centuries variously used some or all of these generic names (e.g. Milne-Edwards, 1880; Faxon, 1893; Alcock, 1901; Balss, 1913; Tirmizi, 1966), although all recognised difficulties in 'satisfactorily' subdividing Munidopsis. For convenience, Alcock (1901) used several such names for informal groupings or subgenera within the single genus Munidopsis. Chace (1942), however, "failed to reveal any natural grouping" and synonymised all of the aforementioned generic names with Munidopsis. Apart from the recent resurrection of Galacantha (Macpherson, 2007), most subsequent workers have followed Chace. Although our representation of morphological diversity in Munidopsis is not yet comprehensive, our topologies already recover several major clades corresponding to previously recognised genera or subgenera.

Shinkaia (Fig. 1K) is sister to a clade of Orophorhynchusgroup species of Munidopsis (Fig. 1G), characterised by a triangular rostrum, a mesially placed distal eye-spine, squamae or short striations on the carapace, and chelipeds that are usually shorter than the second pereiopods. In addition, the Shinkaia and Orophorhynchus clades may share a similar habitat - hydrothermal vents. Many, though not all, species of the Orophorhynchus group are known hydrothermal vent associates, but the sister relationship with Shinkaia suggests that the vent habitat could be ancestral. If the common ancestor of Shinkaia and the Orophorhynchus group was a hydrothermal vent associate, colonisation of deepwater vent habitats can be inferred to have occurred early in the evolution of the munidopsids. At present, the fossil record of munidopsids from chemosynthetic environments is limited to Shinkaia katapsyxis Schweitzer and Feldmann, 2008, from the Eocene Humptulips formation, Western Washington, USA (Schweitzer and Feldmann, 2008). The hydrothermal vent clade (Shinkaia + Orophorhynchus group) is sister to the clade containing Galacantha and the remaining species of Munidopsis, most of which are associated with corals or other complex non-chemosynthetic habitats.

Galacantha (Fig. 1H) is substantially monophyletic and most species form a clade, except for $G$. diomedeae, which is weakly allied to the Bathyankyristes group [diagnosed by the subchelate walking legs and represented by Munidopsis levis (Alcock and Anderson, 1894)] (Fig. 1B). The nodal support excluding $G$. diomedeae from other species of Galacantha is weak, however, so the position may reflect a limitation in the data or an analytical artefact. Morphologically, G. diomedeae differs from other Galacantha in having a scarcely elevated rostrum. In other members of Galacantha the rostrum is distinctly elevated. Additionally the rostrum of $G$. diomedeae lacks any trace of the horizontal portion, which is either distinct or rudimentary in all other species of Galacantha. The taxonomic position of $G$. diomedeae requires reassessment, but is retained in Galacantha pending further corroboration by more extensive analyses.

Interrelationships of the remaining Galacantha exemplars correlate biogeographically, with Western Atlantic (Galacantha spinosa Milne-Edwards, 1880) and Indo-Pacific clades (Galacantha quiquei Macpherson, 2007; Galacantha subspinosa Macpherson, 2007; Galacantha rostrata MilneEdwards, 1880; G. valdiviae Balss, 1913). G. quiquei and G. valdiviae uniquely share single rather than double anterolateral spines on the carapace, and are sister taxa as expected morphologically. In contrast, G. subspinosa and G. spinosa are morphologically similar, and were formerly considered conspecific (Macpherson, 2007). They apparently have a more distant molecular relationship, however, with G. subspinosa more closely allied to its Indo-Pacific congeners than to the western Atlantic G. spinosa.

The type species of Munidopsis, Munidopsis curvirostra Whiteaves, 1874 (Fig. 1I), is sister to a clade of two species corresponding to the Galathopsis group (Fig. 1F). These two species, Munidopsis cylindrophthalma (Alcock, 1894) and Munidopsis crenatirostris Baba, 1988, share a flattened or medially sulcate rostrum, unarmed carapace margins and unarmed abdominal tergites. Neither $M$. cylindrophthalma nor M. crenatirostris were originally placed in Galathopsis, but they closely resemble the two species for which the genus was originally proposed, Munidopsis debilis (Henderson, 1885) and Munidopsis laevigata (Henderson, 1885), respectively. Although, Henderson (1888) subsequently regarded Galathopsis as a junior synonym of Elasmonotus because of the similar carapace shape, our results recovered both groups in separate clades, which differ from each other in abdominal ornamentation. The Elasmonotus group recovered here, containing Munidopsis quadrata Faxon, 1893, M. sp. and Munidopsis longimanus (Milne-Edwards, 1880) (Fig. 1D), is similar to the Galathopsis group in the laterally unarmed, rectangular carapace and broad, simple rostrum, but differs in the medially gibbose anterior abdominal tergites.

The Galathodes group (Fig. 1E) (Munidopsis comarge Taylor et al., 2010, and Munidopsis trifida Henderson, 1885), united by a distally tridentate rostrum is sister to Munidopsis erinacea (Milne-Edwards, 1880) followed by Munidopsis opalescens Benedict, 1902. Although M. erinacea was originally placed in the Galathodes group because of the tridentate rostrum, the rostrum is slender as in $M$. opalescens, rather than broad and flattened as in $M$. comarge and allies such as Munidopsis serricornis (Lovén, 1852) and Munidopsis treis Ahyong and Poore, 2004. The extinct munidopsid genera Paragalathea (lower Jurassic to Paleocene) and Eomunidopsis (Upper Jurassic to Upper Cretaceous) (Schweitzer and Feldmann, 2000), also with broad, distally tridentate rostra may be closely related to the Galathodes group.

Munidopsis dasypus Alcock, 1894 and Munidopsis kensleyi Ahyong and Poore, 2004, form a clade sharing a spiniform rostrum, a subrectangular, transversely convex carapace with anterolateral spines and no eyespines, herein 
referred to as the Dasypus group (Fig. 1C). The fossil munidopsid genus, Gastrosacus (Upper Jurassic to Cretaceous), with a slender rostrum and minimally ornamented carapace, is possibly closely related to the Dasypus group. Munidopsis polymorpha Koelbel, 1892, is ambiguously positioned in our results, but could belong to the Dasypus group; it too has a slender rostrum and minimally armed carapace.

The only Munidopsis synonym not represented in our results is the Anoplonotus group (Fig. 1A), erected for Munidopsis polita (Smith, 1883), but which also includes Munidopsis bruta Macpherson, 2007, Munidopsis granulata Miyake and Baba, 1967, Munidopsis palmatus Khodkina, 1973, Munidopsis truculenta Macpherson and Segonzac, 2005 and Munidopsis vesper Taylor et al., 2010. In these species, the rostrum is simple and narrow, eye-spines are absent, sternite 3 is entirely fused to sternite 4, the carapace regions are well marked, abdominal tergites unarmed and the dactyli of the walking legs are falcate with smooth margins. Henderson (1888) regarded Anoplonotus as a synonym of Elasmonotus because of the similar general carapace outline and elongate chelipeds. The affinities of the Anoplonotus group are not clear, however, but we suspect that similarities to the Elasmonotus group are superficial.

As is evident from the foregoing results, the classification of the munidopsids, both at superfamilial and generic levels requires significant revision. Munidopsis sensu lato is not monophyletic given the phylogenetic positions of Galacantha and Shinkaia. Thus, Shinkaiinae and Munidopsinae cannot be simultaneously maintained without compromising the monophyly of the latter. If a subfamilial structure is to be proposed within Munidopsidae, the most natural division would be between the Leiogalathe a clade, and the clade containing Munidopsis, Galacantha and Shinkaia, both of which have synapomorphies and exhibit sufficient morphological disparity to support taxonomic division.

The major challenge facing generic revision of the Munidopsidae is identifying diagnosable clades within Munidopsis. Chace (1942) regarded meaningful subdivisions of Munidopsis as virtually impossible, but present topologies show that most of the previously proposed genera or subgenera correspond to Munidopsis clades identified herein. These may translate relatively easily into a natural classification. Resurrecting the old generic system, however, would be premature at this stage. The number of known species of Munidopsis sensu lato has doubled since Chace wrote in 1942 and a wider range of forms remains to be analysed to test the validity of the clades indentified herein. Many of the old genera will probably prove valid, but their diagnoses and composition require refinement to accommodate the range of forms now known. The generic system of extant species will need to be coordinated with fossil munidopsid genera and new genera will almost certainly be required. To this end, we are extending our sampling of species and molecular markers with the addition of morphological data toward a comprehensive revision of Munidopsis sensu lato.

\section{Acknowledgements}

We are grateful to Javier Sellanes (UCN), Kareen Schnabel (NIWA) and Darryl Felder (ULL) for freely sharing munidopsid tissue samples. Heather Bracken (BYU) kindly provided photographs of Galacantha valdiviae from the BYU collection and Darryl Felder and Brent Thoma (ULL) checked specimens for us in the ULL collection. We also thank the Census of Marine Life through the field project COMARGE for supporting our work on squat lobster phylogenetics and for supporting symposia at the Seventh International Crustacean Congress, Qingdao, China, 2010. This work was partially funded through the Commonwealth Environment Research Facilities (CERF) program, an Australian Government initiative. The CERF Marine Biodiversity Hub is a collaborative partnership between the University of Tasmania, CSIRO Wealth from Oceans Flagship, Geoscience Australia, Australian Institute of Marine Science and Museum Victoria.

\section{References}

Ahyong, S.T., Poore, G.C.B., 2004. Deep-water Galatheidae (Crustacea: Decapoda: Anomura) from southern and eastern Australia. Zootaxa 472, 3-76.

Ahyong, S.T., Schnabel, K.E., Maas, E., 2009. Anomuran phylogeny: new insights from molecular data. In: Martin, J.W., Crandall, K., Felder, D.F. (Eds.), Decapod Crustacean Phylogenetics. Crustacean Issues, 18, pp. 399-414.

Ahyong, S.T., Baba, K., Macpherson, E., Poore, G.C.B., 2010. A new classification of the Galatheoidea (Crustacea: Decapoda: Anomura). Zootaxa 2676, 57-68.

Alcock, A., 1894. Natural history notes from H.M. Royal Indian Marine Survey Steamer "Investigator", commander R.F. Hoskin. R. N., commanding. - Series II, No. 1. On the results of deep-sea dredging during the season of 1890-91 (continued). Annals and Magazine of Natural History (6) 13, 321-334.

Alcock, A., 1901. A descriptive catalogue of the Indian deepsea Crustacea Decapoda Macrura and Anomala in the Indian Museum. Being a revised account of the deep-sea species collected by the Royal Indian Marine Survey Ship Investigator. In: Trustees of the Indian Museum, Calcutta, p. 286, pls 1-3.

Alcock, A., Anderson, A.R.S., 1894. Natural history notes from H.M. Royal Indian Marine Survey Steamer "Investigator", commander C.F. Oldham, R.N., commanding. - Series II. No. 14. An account of a recent collection of deep-sea Crustacea from the Bay of Bengal and Laccadive Sea. Journal of the Asiatic Society of Bengal (Natural History) 63, 141-185, pl. 9.

Alcock, A., Anderson, A.R.S., 1895. Crustacea, Part III. Illustrations of the zoology of the Royal Indian Marine Surveying Steamer Investigator, under the Command of Commander A. Carpenter, R.N., D.S.O., of the Late Commander R.F. Hoskyn, R.N., and of Commander C.F. Oldham. In: Trustees of the Indian Museum, Calcutta, pls 9-15.

Alcock, A., McArdle, S.B., 1901. Crustacea, Part XIX. Illustrations of the zoology of the Royal Indian Marine Surveying Steamer "Investigator". In: Trustees of the Indian Museum, Calcutta, pls 49-55. 
Alcock, A., McArdle, S.B., 1902. Crustacea, Part X. Illustrations of the zoology of the Royal Indian Marine Surveying Steamer "Investigator". In: Trustees of the Indian Museum, Calcutta, pls 55-67.

Alcock, A., MacGilchrist, A.C., 1905. Crustacea, Part XI. Illustrations of the zoology of the Royal Indian Marine Surveying Steamer "Investigator". In: Trustees of the Indian Museum, Calcutta, pls 68-76.

Aljanabi, S.M., Martinez, I., 1997. Universal and rapid salt-extraction of high quality genomic DNA for PCR-based techniques. Nucleic Acids Research 25, 4692-4693.

Baba, K., Macpherson, E., Poore, G.C.B., Ahyong, S.T., Bermudez, A., Cabezas, P., Lin, C.-W., Nizinski, M., Rodrigues, C., Schnabel, K., 2008. Catalogue of squat lobsters of the world (Crustacea: Decapoda: Anomura - families Chirostylidae, Galatheidae and Kiwaidae). Zootaxa 1905, 1-220.

Balss, H., 1913. Ostasiatische Decapoden I. Die Galatheiden und Paguriden. In: Doflein, F. (Ed.), Beitraege zur Naturgeschichte Ostasiens. Abhandlungen der MathematischPhysikalischen Klasse der Königlich Bayerischen Akademie der Wissenschaften, 2., pp. 1-85, pls 1, 2.

Chace, F.A., 1942. The Anomura Crustacea I. Galatheidea. Reports of the scientific results of the Atlantis Expeditions to the West Indies, under the joint auspices of the University of Havana and Havard University. Torreia, 11, pp. 1-106.

Creasey, S., Rogers, A., Tyler, J., Gage, J., Jollivet, D., 2000. Genetic and morphometric comparisons of squat lobster, Munidopsis scobina (Decapoda: Aanomura: Galatheidae) populations, with notes on the phylogeny of the genus Munidopsis. Deep Sea Research II 47, 87-118.

Cubelio, S.S., Tsuchida, S., Hendrickx, M.E., Kado, R., Watanabe, S., 2007. A new species of vent associated Munidopsis (Crustacea: Decapoda: Anomura: Galatheidae) from the Western Pacific, with notes on its genetic identification. Zootaxa 1435, 25-36.

Doflein, F., Balss, H., 1913. Die Galatheiden der Deutschen TiefseeExpedition. In: Wissenschaftliche Ergebnisse der Deutschen Tiefsee-Expedition auf dem Dampfer "Valdivia", 1898-1899 20, pp. $125-184$, pls 12-17.

Edgar, R.C., 2004. MUSCLE: multiple sequence alignment with high accuracy and high throughput. Nucleic Acids Research 32, 1792-1797.

Faxon, W., 1893. Reports on the dredging operations off the west coast of Central America to the Galapagos, to the west coast of Mexico, and in the Gulf of California, in charge of Alexander Agassiz, carried on by the U.S. Fish Commission Steamer "Albatross", during 1891, Lieut.-Commander Z.L. Tanner, U.S.N., commanding. VI. Preliminary descriptions of new species of Crustacea. Bulletin of the Museum of Comparative Zoology at Harvard College 24, 149-220.

Felsenstein, J., 1985. Confidence limits on phylogenies: an approach using the bootstrap. Evolution 39, 783-791.

Folmer, O., Black, M., Heoh, W., Lutz, R.A., Vrijenhoek, R., 1994. DNA primers for the amplification of mitochondrial cytochrome $\mathrm{C}$ oxidase subunit I from diverse metazoan invertebrates. Molecular Marine Biology and Biotechnology 3, 294-299.

Guindon, S., Gascuel, O., 2003. A simple, fast, and accurate algorithm to estimate large phylogenies by maximum likelihood. Systematic Biology 52, 696-704.
Hall, T.A., 1999. BioEdit: a user-friendly biological sequence alignment editor and analysis program for Windows 95/98/NT. Nucleic Acids Symposium 41, 95-98.

Henderson, J.R., 1885. Diagnoses of new species of Galatheidae collected during the "Challenger" expedition. Annals and Magazine of Natural History (ser 5) 16, 407-421.

Henderson, J.R., 1888. Report on the Anomura collected by H.M.S., Challenger during the years 1873-76. Report on the Scientific Results of the Voyage of H.M.S. Challenger during the years 1873-76. Zoology 27, 1-221, 21 pls.

Hillis, D.M., Huelsenbeck, J.P., 1992. Signal, noise and reliability in molecular phylogenetic analysis. Journal of Heredity 83, 189-195.

Huelsenbeck, J.P, Ronquist, F., 2001. MRBAYES: Bayesian inference of phylogenetic trees. Bioinformatics 17, 754-755.

Jones, W.J., Macpherson, E., 2007. Molecular phylogeny of the East Pacific squat lobsters of the genus Munidopsis (Decapoda: Galatheidae) with the descriptions of seven new species. Journal of Crustacean Biology 27, 477-501.

Khodkina, I.V., 1973. New species of the genus Munidopsis (Decapoda, Anomura) from the east Pacific. Zoologicheskii Zhurnal, Moscow 52, 1156-1167 (In Russian with English summary).

Lovén, S., 1852. De svenska arterna af slägtet Galathea. Ofversigt af Konglige Vetenskaps-Akademiens Förhandlingar 9, 2023.

Macpherson, E., 2007. Species of the genus Munidopsis Whiteaves, 1784 from the Indian and Pacific Oceans and reestablishment of the genus Galacantha A. Milne-Edwards, 1880 (Crustacea, Decapoda, Galatheidae). Zootaxa 1417, 1-135.

Macpherson, E., Segonzac, M., 2005. Species of the genus Munidopsis (Crustacea, Decapoda Galatheidae) from the deep Atlantic Ocean, including cold-seep and hydrothermal vent areas. Zootaxa 1095, 1-60.

Milne-Edwards, A., 1880. Reports on the results of dredging under the supervision of Alexander Agassiz, in the Gulf of Mexico and in the Caribbean Sea, etc., VIII. Études préliminaires sur les Crustacés. Bulletin of the Museum of Comparative Zoology at Harvard College 8, 1-168, pls 1-2.

Milne-Edwards, A., Bouvier, E.L., 1897. Reports on the results of dredging, under the supervision of Alexander Agassiz, in the Gulf of Mexico (1877-78), in the Caribbean Sea (1878-79), and along the Atlantic coast of the United States (1880), by the U.S. Coast Survey steamer "Blake," Lieut.-Com. C.D. Sigsbee, U.S.N., and Commander J.R. Bartlett, U.S.N., commanding. XXXV: Description des Crustacés de la Famille des Galathéidés recueillis pendant l'expédition. In: Memoirs of the Museum of Comparative Zoology at Harvard College, 19, pp. 5-141, pls 1-10.

Miyake, S., Baba, K., 1967. New and rare species of the family Galatheidae (Crustacea, Anomura) from the Sagami Bay in the collection of the Biological Laboratory, Imperial Household, Japan. Journal of the Faculty of Agriculture Kyushu University $14,213-224$.

Palumbi, S.R., Benzie, J., 1991. Large mitochondrial DNA differences between morphologically similar penaeid shrimp. Marine Biology and Biotechnology 1, 27-34.

Posada, D., Crandall, K.A., 1998. Modeltest: testing the model of DNA substitution. Bioinformatics 14, 817-818.

Rambaut, A., Drummond, A.J., 2007. Tracer v1.4, Available from: http://beast.bio.ed.ac.uk/Tracer. 
Schnabel, K.E., Ahyong, S.T., Maas, E.W., 2011. Galatheoidea are not monophyletic - molecular and morphological phylogeny of the squat lobsters (Decapoda: Anomura) with recognition of a new superfamily. Molecular Phylogenetics and Evolution 58, $157-168$

Schweitzer, C.E., Feldmann, R.M., 2000. First notice of the Chirostylidae (Decapoda) in the fossil record and new Tertiary Galatheidae (Decapoda) from the Americas. Bulletin of the Mizunami Fossil Museum 27, 147-165.

Schweitzer, C.E., Feldmann, R.M., 2008. New Eocene hydrocarbon seep decapod crustacean (Anomura: Galatheidae: Shinkaiinae) and its paleobiological implications. Journal of Paleontology 82, 1021-1029.

Selbie, C.M., 1914. The Decapoda Reptantia of the coasts of Ireland. Part 1. Palinura, Astacura and Anomura (except Paguridea). Fisheries Ireland Scientific Investigations 1, 1-116, pls 1-15.

Smith, S.I., 1883. Preliminary report on the Brachyura and Anomura dredged in deep water off the south coast of New England by the United States Fish Commission in 1880, 1881, and 1882. Proceedings of the United States National Museum 6, 1-57, pls $1-6$.

Smith, S.I., 1884. Report on the decapod Crustacea of the "Albatross" dredgings off the east coast of the United States in 1883.
Report of the Commission on Fish and Fisheries 10, 345-426, pls $1-10$.

Swofford, D.L., 2002. PAUP*. Phylogenetic Analysis Using Parsimony (*and Other Methods). Version 4. Sinauer Associates, Sunderland.

Taylor, J., Ahyong, S.T., Andreakis, N., 2010. New records and new species of the munidopsine squat lobsters (Decapoda: Anomura: Galatheidae: Munidopsinae) from Australia. Zootaxa $2642,1-18$.

Thompson, J.D., Higgins, D.G., Gibson, T.J., 1994. CLUSTAL W: improving the sensitivity of progressive multiple sequence alignment through sequence weighting, position specific gap penalties and weight matrix choice. Nucleic Acids Research 22, 4673-4680.

Tirmizi, N.M., 1966. Crustacea: Galatheidae. The John Murray Expedition 1933-34. Scientific Reports 11, 167-234.

Toon, A., Finley, M., Staples, J., Crandall, K.A., 2009. Decapod phylogenetics and molecular evolution. In: Martin, J.W., Crandall, K.A., Felder, D.L. (Eds.), Advances in Decapod Phylogenetics. Crustacean Issues, 18, pp. 15-29.

Whiteaves, J.F., 1874. On recent deep-sea dredging operations in the Gulf of St. Lawrence. American Journal of Science (ser. 3) 7, 210-219. 